\title{
THE RELATIONSHIP OF ENTREPRENEURIAL SOUL AND INTRODUCTION OF INFORMATION TECHNOLOGY TO UNDERSTANDING OF ACCOUNTING INFORMATION QUALITY
}

\author{
MF DJENI INDRAJATI \\ ELIZABETH SUGIARTO DERMAWAN
}

Faculty of Economics, Tarumanagara University, Jl. Tanjung Duren Utara No. 1, Jakarta Barat 11470, Indonesia djenii@fe.untar.ac.id

\begin{abstract}
This research was conducted to illustrate the readiness of S1 Accounting students in entrepreneurship and their readiness to compete through familiar information technology that can relate to their understanding of the quality of accounting information that is ultimately needed for decision-making and accountability. The results of this study indicate the link between the Entrepreneurial Soul and the introduction of positive and significant information technology to the quality of accounting information. By looking at the correlation coefficient, Entrepreneurial Soul has a higher correlation coefficient on understanding Accounting Information Quality than Introduction to Information Technology on understanding Accounting Information Quality. Therefore, in order to increase understanding of the Quality of Accounting Information, it is necessary to improve the Entrepreneurial Soul and Introduction of Information Technology.
\end{abstract}

Keywords: Entrepreneurial soul, introduction to information technology, information quality accounting

\section{INTRODUCTION}

Facing global competition, entrepreneurs need to be given insight into values that must be maintained, among others Susanto (2016) argues that integrity, honesty, perseverance, hard work, creativity, long-term orientation, and generosity. The era of technological development cannot be dammed, innovations are emerging, business competition is getting tougher, companies can not ignore these pressures. Therefore, quality information is needed for accountability and decisionmaking. Kelly, Bosma, and Amoros (2011) in Kabui and Maalu (2012) suggested indicators of entrepreneurial attitudes from the results of surveys in 59 countries, related to what people think about the opportunity to start a business, the sense of being able to do it, their fear of failure, and how much risk you want to take. Shinnar, Pruelt, and Bryan (2010) in Kabui and Maalu (2012) revealed the results of their research on the attitudes of students who did not study business towards entrepreneurship at the Northern Carolina Universities found that parents play an important role in shaping student attitudes. Curran (1996) in Henderson and Robertson (1999) in Kabui and Maalu (2012) revealed the results of his research on high school students in Scotland and found that teachers and the media had a major influence on students' perceptions of entrepreneurship, 
unfortunately the findings revealed that teachers and television provided a picture negative for entrepreneurs as someone who often faces the fear of money. Nian, Bakar, and Islam (2014) revealed the results of their research on students undertaking entrepreneurship education at the University of Malaysia Perlis that entrepreneurship education plays an important role in developing entrepreneurship. Martz, Neil, Biscaccianti, and Williams (2003) suggested the results of research on entrepreneurial perceptions of students across three cultures (American, French, and English) that differed based on the curriculum taught and from 258 questionnaires showed differences. American students feel that the entrepreneurial lifestyle is better and want to have that lifestyle more than students from France and Britain.

Maharsi (2000) proposed the definition of information technology as a combination of computer and telecommunications technology with other technologies such as hardware, software, databases, network technology, and other telecommunications equipment. Maharsi (2000) stated the results of his research revealed that the development of information technology brought significant changes to the business world and could have beneficial and detrimental effects on the field of management accounting. Yuliana (2000) suggested that advances in technology, computers, and telecommunications support the development of internet technology that can provide business strategy advantages to win competition in global dissemination, interaction, customization, collaboration, electronic commerce, and integration.

Sari and Yadnyana (2017) revealed that the quality of accounting information is part of the measurement and effectiveness of an information system with indicators of flexibility, ease of use, and system reliability. IAI (2017) suggests that fundamental qualitative characteristics consist of relevance and precise representation. Relevance means financial information can make a difference in users' decisions that have predictive value, confirmatory value, and both. The right presentation can be seen from complete, neutral and error free. Matovu (2005) suggests the results of his research that there is a significant positive relationship between the quality of accounting information and the performance of Small and Medium Enterprises. The quality of accounting information related to relevance, accuracy, comprehension, and reliability improves the performance of Small and Medium Enterprises. Suryani (2009) in Lestari and Fun (2015) suggested that accounting knowledge and the use of accounting software either partially or simultaneously have a significant effect on individual performance, thus accountants who have an understanding of accounting can carry out tasks lightly. Yuliani et al (2010) in Lestari and Fun (2015) argued that in order to produce quality financial reports, the quality of the people who carry out the task must understand and understand the accounting process and implementation in accordance with applicable regulations.

Sari and Yadnyana (2017) revealed the results of their research are in line with the results of research by Suhairi (2004) and Krisanti (2012) that there is a positive and significant influence between the entrepreneurial spirit on the quality of accounting information. On the other hand, Sari and Yadnyana (2017) also revealed that the research results of Galloway et al (2006) which results found that there was no significant influence of the entrepreneurial spirit with the interests of students using accounting software. Sari and Yadnyana (2017) revealed the results of their research are in line with the research results of Ismail and King (2007), Al-Eqab and Adel (2013), and Rahmadani (2015) that there is a positive and significant influence between the sophistication of information technology and the quality of accounting information. On the other hand, Sari and Yadnyana (2017) also 
revealed that the research of Purnama (2013) and Rai et al (2002) found a different direction, namely the sophistication of information technology had a negative effect on the quality of accounting information. This research was inspired by Sari and Yadnyana's research (2017) which revealed the results of his research that the sophistication of information technology and entrepreneurial spirit had a positive effect on the quality of accounting information. The formulation of the problem in this study is as follows: (1) how is the perception of undergraduate students studying accounting for their Entrepreneurial Soul, (2) how is the perception of undergraduate students studying accounting for the introduction of Information Technology owned, (3) how is the perception of undergraduate students studying accounting above Understanding of the Quality of Accounting Information possessed, and (4) Is there a positive relationship between the Entrepreneurial Soul and the Introduction of Information Technology to Understanding of Accounting Information Quality. Using primary data this research model can be illustrated in Figure 1 below.

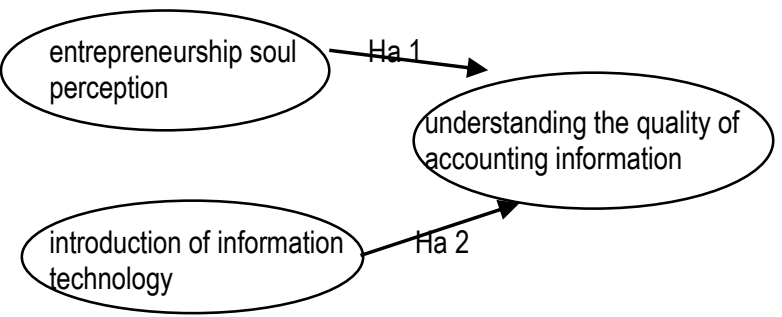

Figure 1 Research Model

\section{The Relationship of Entrepreneurship and Quality of Accounting Information}

The accounting students 'perception of Entrepreneurial Soul refers to Kabui and Maalu (2012) measured by respondents' perceptions of: (1) motivational statements, entrepreneurial characteristics, entrepreneurial challenges, and (4) success in entrepreneurship. Referring to the Theory of Planned Behavior, it is expected that respondents who have a high perception of the Entrepreneurial Soul are expected to have the intention to behave in understanding the quality of accounting information better. Therefore the first alternative hypothesis of this study is:

$\mathrm{H}_{1}$ : S1 accounting students' perceptions of the Entrepreneurial Soul are positively related to perceptions of accounting undergraduate students on the Quality of Accounting Information.

\section{The Relationship between Introduction of Information Technology and Quality of Accounting Information}

S1 accounting students 'perceptions of the introduction of Information Technology referring to Sidiq \& Astutik (2017) were measured by respondents' perceptions of the introduction of: (1) infrastructure, (2) networking, (3) expertise, (4) management, (5) development, and (6) ) collection. Referring to the Theory of Planned Behavior, it is expected that respondents who have a high perception on the introduction of Information Technology are expected to have the intention to behave to understand the quality of accounting information better. Therefore the second alternative hypothesis of this study is:

$\mathrm{H}_{2}$ : S1 accounting students 'perceptions of the introduction of Information Technology are positively related to accounting S1 students' perceptions of the Quality of Accounting Information

\section{RESEARCH METHODS}

University students from several regions in Indonesia became the population of this study. The sample of this study were respondents consisting of undergraduate students at Tarumanagara University, Pelita Harapan University, Krida Wacana University, and STIE Trisakti. This research variable modifies the results of factor analysis from measures that have been tested by several previous studies. The dependent variable in this 
study is the perception of undergraduate accounting students on the Quality of Accounting Information. The independent variable consists of the perception of undergraduate accounting students on the Entrepreneurial Soul and Introduction to Information Technology. The hypothesis testing technique in this study is to use Smart PLS3. Validity test refers to (1) loading factor $>0.05$ to the intended construct, (2) average variance extracted (AVE) $>0.5$. The reliability test is done by looking at the Cronbach's Alpha value for the results of a valid questionnaire answer with a value greater than 0.7 so that it can be said to be reliable (Latan \& Ghozali, 2012). Table 1 below illustrates the operationalization of the variables of this study.

\section{Table 1 Operational Variables}

\begin{tabular}{|c|c|c|c|c|}
\hline No & Variable & Indicator* & Scale & Data Source \\
\hline 1. & $\begin{array}{l}\text { S1 } \\
\text { accounting } \\
\text { students' } \\
\text { perceptions } \\
\text { of the } \\
\text { Quality of } \\
\text { Accounting } \\
\text { Information }\end{array}$ & $\begin{array}{l}\text { - } \text { Relevance (KIARLV 1- } \\
\text { 14) } \\
\text { - } \text { Faithfull } \\
\text { Representation } \\
\text { (KIART 1-12) }\end{array}$ & Ordinal & $\begin{array}{l}\text { Respondents } \\
\text { Questionnaire } \\
\text { Answers } \\
\text { referring to } \\
\text { Matovu (2005) }\end{array}$ \\
\hline 2. & $\begin{array}{l}\text { S1 } \\
\text { accounting } \\
\text { students' } \\
\text { perception } \\
\text { of } \\
\text { Entrepreneu } \\
\text { rial Soul }\end{array}$ & $\begin{array}{l}\text { - Statement of } \\
\text { motivation (JKPM 1-9) } \\
\text { - Entrepreneurial } \\
\text { characteristic } \\
\text { (JKKW1-5) } \\
\text { - Entrepreneurial } \\
\text { challanges (JKTW 1- } \\
\text { 9) } \\
\text { - Success in } \\
\text { entrepreneurship } \\
\text { (JKSK 1-5) }\end{array}$ & Ordinal & $\begin{array}{l}\text { Respondents } \\
\text { Questionnaire } \\
\text { Answers that } \\
\text { refer to Kabui } \\
\text { and Maalu } \\
\text { (2012) }\end{array}$ \\
\hline 3. & $\begin{array}{l}\text { S1 students' } \\
\text { perceptions } \\
\text { of } \\
\text { accounting } \\
\text { for the } \\
\text { introduction } \\
\text { of } \\
\text { Information } \\
\text { Technology }\end{array}$ & $\begin{array}{ll}\text { - } & \text { infrastructure (PTI1) } \\
\text { - } & \text { networking (PTI2) } \\
\text { - } & \text { expertise (PTI3) } \\
\text { - } & \text { management (PTI4) } \\
\text { - } & \text { development (PTI5) } \\
\text { - } & \text { collection. (PTI6) }\end{array}$ & Ordinal & $\begin{array}{l}\text { Respondents } \\
\text { Questionnaire } \\
\text { Answers } \\
\text { referring to } \\
\text { Sidiq \& Astutik } \\
\text { (2017) }\end{array}$ \\
\hline
\end{tabular}

\section{RESULTS}

The questionnaires distributed in this study amounted to 375 but there were 8 that were not answered so the study was conducted based on 367 respondents' questionnaire
answers.Based on 367 respondents' answers can be classified by college, respondent's age, gender, reasons for studying Accounting, and the semester being taken when completing this questionnaire as follows:

\begin{tabular}{|l|r|}
\hline \multicolumn{2}{|c|}{$\begin{array}{c}\text { College of } \\
\text { Respondents }\end{array}$} \\
\hline UNTAR & 213 \\
\hline UPH & 83 \\
\hline STIE Trisakti & 58 \\
\hline Ukrida & 13 \\
\hline
\end{tabular}

\begin{tabular}{|l|r|}
\hline \multicolumn{2}{|c|}{$\begin{array}{c}\text { Gender of } \\
\text { Respondents }\end{array}$} \\
\hline Male & 125 \\
\hline Female & 242 \\
\hline
\end{tabular}

\begin{tabular}{|l|r|}
\hline \multicolumn{2}{|c|}{$\begin{array}{c}\text { Age of } \\
\text { respondent }\end{array}$} \\
\hline 17 years & 3 \\
\hline 18 years & 31 \\
\hline 19 years & 123 \\
\hline 20 years & 154 \\
\hline 21 years & 47 \\
\hline 22 years & 3 \\
\hline 23 years & 3 \\
\hline 24 years & 1 \\
\hline 25 years & 1 \\
\hline 26 years & 1 \\
\hline
\end{tabular}

\begin{tabular}{|l|r|}
\hline \multicolumn{2}{|c|}{$\begin{array}{c}\text { Reasons to Take S1 } \\
\text { Accounting Study } \\
\text { Program }\end{array}$} \\
\hline Personal interest & 252 \\
\hline Asked by parents & 108 \\
\hline Follow friends & 7 \\
\hline
\end{tabular}

\begin{tabular}{|l|r|}
\hline \multicolumn{2}{|c|}{ Currently Respondents are in Semester } \\
\hline 2 & 35 \\
\hline 4 & 125 \\
\hline 5 & 48 \\
\hline 6 & 159 \\
\hline
\end{tabular}

The object of the study consisted of students' perceptions of Accounting Information Quality $(\mathrm{KIA})$, Entrepreneurial Soul (JK), and Introduction to Information Technology (PTI). The loading factor value of the reflective indicator that is declared valid is greater than 0.5 and the average variance extracted (AVE) value is above 0.5. Associated with the reliability test seen from the Cronbachs Alpha value of more than 0.7 . The results of validity and reliability tests can be seen in Table 2 and Table 3 below. 
Table 2

Outer Loading Factor Results

\begin{tabular}{|l|l|l|l|l|l|l|l|l|}
\hline & JK & JKKW & JKPM & JKSK & KIA & KIALV & KIART & PTI \\
\hline JKKW1 & & 0.796 & & & & & & \\
\hline JKKW1 & 0.741 & & & & & & & \\
\hline JKKW2 & & 0.930 & & & & & & \\
\hline JKKW2 & 0.807 & & & & & & & \\
\hline JKKW3 & & 0.897 & & & & & & \\
\hline JKKW3 & 0.803 & & & & & & & \\
\hline JKKW5 & & 0.864 & & & & & & \\
\hline JKKW5 & 0.792 & & & & & & & \\
\hline JKPM1 & & & 0.813 & & & & & \\
\hline JKPM1 & 0.671 & & & & & & & \\
\hline JKPM2 & & & 0.846 & & & & & \\
\hline JKPM2 & 0.722 & & & & & & & \\
\hline JKPM5 & & & 0.769 & & & & & \\
\hline JKPM5 & 0.635 & & & & & & & \\
\hline JKPM6 & & & 0.785 & & & & & \\
\hline JKPM6 & 0.697 & & & & & & & \\
\hline JKSK2 & & & & 0.839 & & & & \\
\hline JKSK2 & 0.675 & & & & & & & \\
\hline JKSK3 & & & & 0.767 & & & & \\
\hline JKSK3 & 0.530 & & & & & & & \\
\hline JKSK4 & & & & 0.836 & & & & \\
\hline JKSK4 & 0.693 & & & & & & & \\
\hline KIARLV10 & & & & & & 0.785 & & \\
\hline KIARLV10 & & & & & 0.679 & & & \\
\hline KIARLV11 & & & & & & 0.747 & & \\
\hline KIARLV11 & & & & & 0.672 & & & \\
\hline KIARLV12 & & & & & & 0.771 & & \\
\hline KIARLV12 & & & & & 0.701 & & & \\
\hline
\end{tabular}

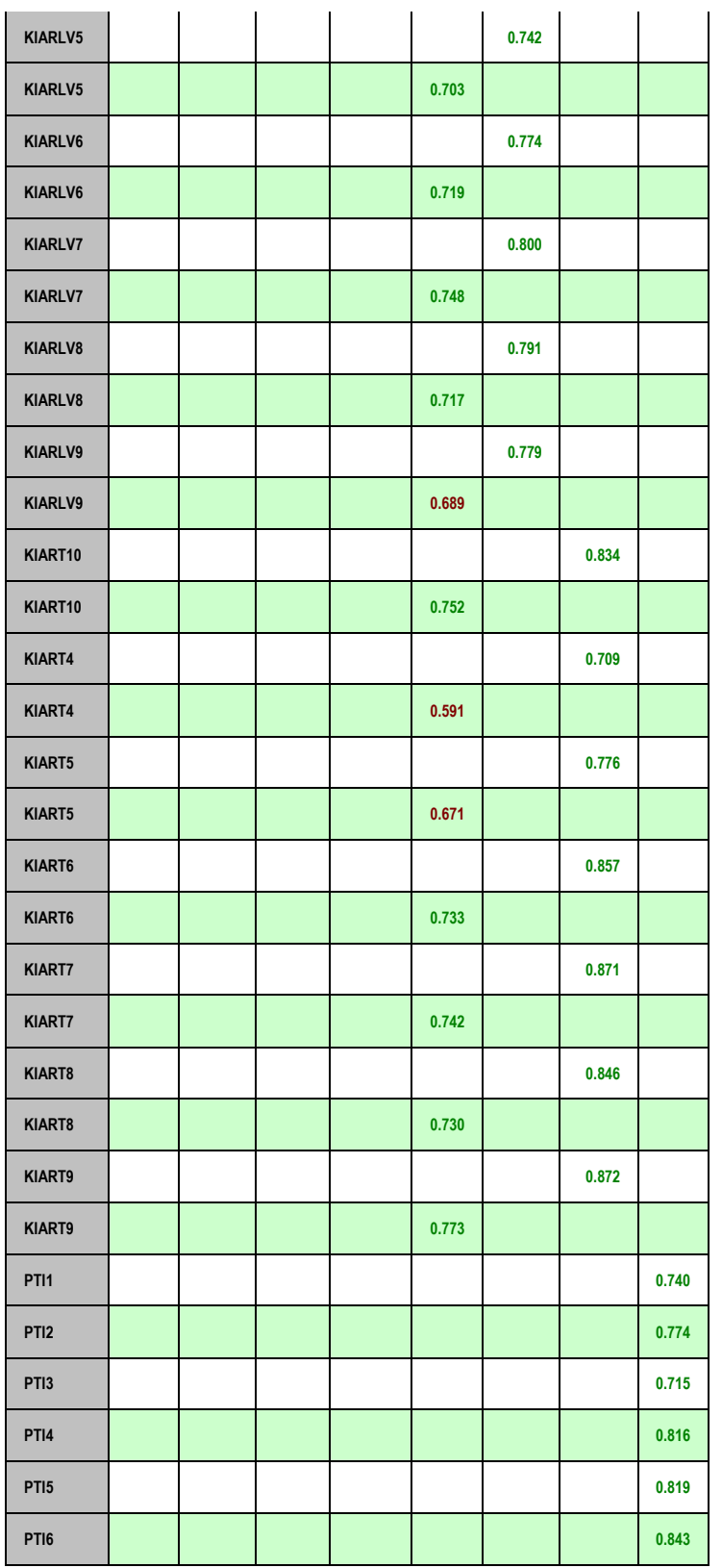


Table 3

Constract Reliability and Validity Results

\begin{tabular}{|l|r|r|}
\hline & $\begin{array}{c}\text { Cronbach's } \\
\text { Alpha }\end{array}$ & $\begin{array}{c}\text { Average Variance } \\
\text { Extracted (AVE) }\end{array}$ \\
\hline JK & 0.900 & 0.504 \\
\hline JKKW & 0.895 & 0.763 \\
\hline JKPM & 0.817 & 0.646 \\
\hline JKSK & 0.748 & 0.663 \\
\hline KIA & 0.933 & 0.502 \\
\hline KIALV & 0.915 & 0.597 \\
\hline KIART & 0.921 & 0.681 \\
\hline PTI & 0.879 & 0.617 \\
\hline
\end{tabular}

In Tables 2 and 3 above, the question items (indicators) of each of these variables that pass the validity and reliability test are:

\begin{tabular}{|c|c|}
\hline Independent Variable & Dependent Variable \\
\hline $\begin{array}{ll}\text { - } & \text { JKPM 1,2,5,\& } 6 \\
\text { - } & \text { JKKW 1,2,3,\& } 5 \\
\text { - } & \text { JKSK 2,3,\& } 4 \\
\text { - } & \text { PTI 1,2,3,4,5,\& } 6\end{array}$ & $\begin{array}{ll}- & \text { KIART 4,5,6,7,8,9, \& } 10 \\
\text { - } & \text { KIARLV 4,5,6,7,8,9,10,11, } \\
& \& 12\end{array}$ \\
\hline
\end{tabular}

JKTW 1-9 did not pass the validity and reliability test so it was not included in this study.

Descriptions of each indicator of KIA, $\mathrm{JK}$, and PTI variables that have been tested for validity and reliability are presented with minimum, maximum, mean, and standard deviation values are presented in Table 4 below.

Table 4

Descriptive Statistics

\begin{tabular}{|l|r|r|r|r|r|}
\hline & N & \multicolumn{1}{|c|}{ Minimum } & $\begin{array}{c}\text { Maximu } \\
\mathrm{m}\end{array}$ & Mean & \multicolumn{1}{c|}{$\begin{array}{c}\text { Std. } \\
\text { Deviation }\end{array}$} \\
\hline KIART4 & 367 & 1.00 & 6.00 & 4.6431 & 1.29547 \\
KIART5 & 367 & 1.00 & 6.00 & 4.6485 & 1.07589 \\
KIART6 & 367 & 1.00 & 6.00 & 4.6703 & .95687 \\
KIART7 & 367 & 1.00 & 6.00 & 4.6567 & 1.00917 \\
KIART8 & 367 & 1.00 & 6.00 & 4.6158 & .95932 \\
\hline
\end{tabular}

\begin{tabular}{|c|c|c|c|c|c|}
\hline KIART9 & 367 & 1.00 & 6.00 & 4.6131 & .95965 \\
\hline KIART10 & 367 & 1.00 & 6.00 & 4.7657 & .95220 \\
\hline KIARLV4 & 367 & 1.00 & 6.00 & 4.8147 & .91347 \\
\hline KIARLV5 & 367 & 2.00 & 6.00 & 4.8065 & .86091 \\
\hline KIARLV6 & 367 & 2.00 & 6.00 & 4.8311 & .91066 \\
\hline KIARLV7 & 367 & 1.00 & 6.00 & 4.8856 & .88890 \\
\hline KIARLV8 & 367 & 1.00 & 6.00 & 4.8420 & .93334 \\
\hline KIARLV9 & 367 & 1.00 & 6.00 & 4.8365 & .94405 \\
\hline KIARLV10 & 367 & 1.00 & 6.00 & 4.8311 & .93436 \\
\hline KIARLV11 & 367 & 1.00 & 6.00 & 4.7302 & .99492 \\
\hline KIARLV12 & 367 & 1.00 & 6.00 & 4.8583 & .92422 \\
\hline JKPM1 & 367 & 1.00 & 6.00 & 4.9837 & 1.14508 \\
\hline JKPM2 & 367 & 1.00 & 6.00 & 5.0899 & .95247 \\
\hline JKPM5 & 367 & 1.00 & 6.00 & 4.9510 & 1.04688 \\
\hline JKPM6 & 367 & 2.00 & 6.00 & 5.1417 & .97599 \\
\hline JKKW1 & 367 & 1.00 & 6.00 & 5.4305 & .89622 \\
\hline JKKW2 & 367 & 1.00 & 6.00 & 5.5477 & .86035 \\
\hline JKKW3 & 367 & 1.00 & 6.00 & 5.5395 & .80839 \\
\hline JKKW5 & 367 & 1.00 & 6.00 & 5.6185 & .78683 \\
\hline JKSK2 & 367 & 2.00 & 6.00 & 5.1199 & .98170 \\
\hline JKSK3 & 367 & 1.00 & 6.00 & 4.9755 & 1.07223 \\
\hline JKSK4 & 367 & 1.00 & 6.00 & 5.2807 & 1.00829 \\
\hline PTI1 & 367 & 1.00 & 6.00 & 3.9537 & 1.18761 \\
\hline PTI2 & 367 & 1.00 & 6.00 & 4.2779 & 1.24318 \\
\hline
\end{tabular}




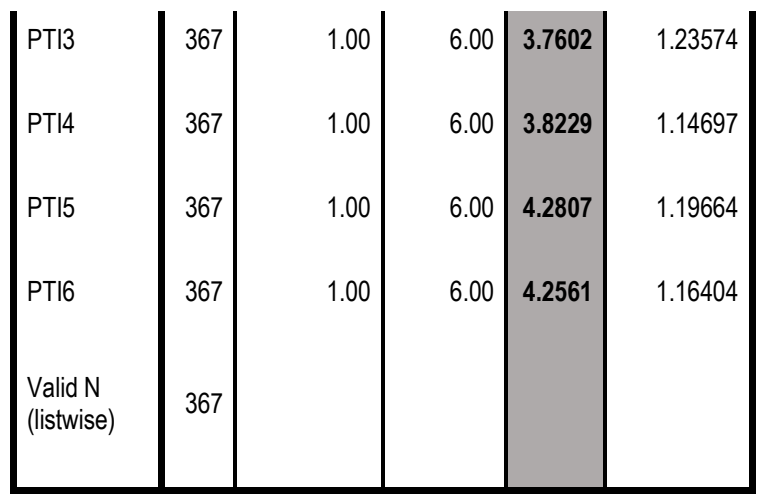

Based on Table 4 above, it can be stated that the average respondent answers valid questionnaire items for both the dependent variable $(\mathrm{KIA})$ and the independent variable $(\mathrm{JK}$ $\& \mathrm{PTI}$ ) the results are above 4 and 5 so that it can be stated that the average respondent answers tend to agree.

The test results with Smart PLS3 show the positive influence of Entrepreneurial Soul and Introduction of Information Technology to the Quality of Accounting Information, the results can be seen in Figure 2 below.

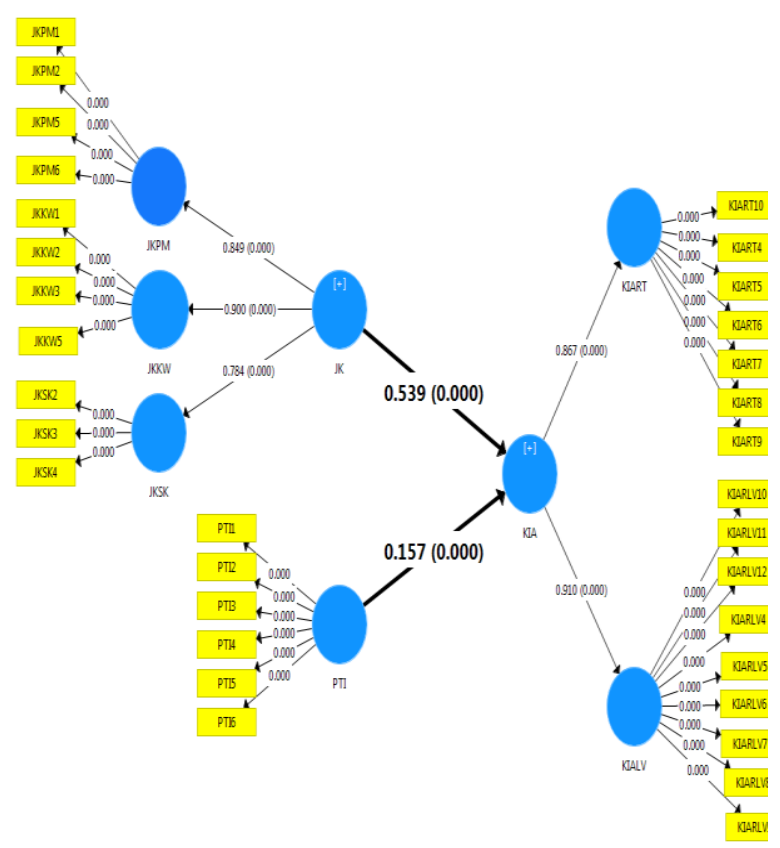

Figure 2 Hypothesis Test Results
Based on Figure 2 shows that the Entrepreneurship Soul (JK) has a significant effect on the Quality of Accounting Information (KIA) with a positive correlation coefficient of 0.539 , thus Ha1 is accepted.The introduction of Information Technology (PTI) has a significant effect on the Quality of Accounting Information (KIA) with a positive correlation coefficient of 0.157 , thus $\mathrm{Ha} 2$ is accepted.

\section{Perception of Undergraduate Students Studying Accounting for the Entrepreneurial Soul.}

Referring to Kabui and Maalu (2012), indicators of the perception of undergraduate students studying accounting for the Entrepreneurial Soul in this study are Motivation Statement (PM), Entrepreneurial Characteristics (KW), Entrepreneurial Challenges (TW), and Success in Entrepreneurship (SK). Based on the respondent's answer related to the indicators of Entrepreneurial Soul for all valid statements, see Table 3 above.

Respondents' answers to a valid and reliable Motivation Statement (JKPM) have an average value of between 4 and 5 from the Likert scale range of 1 to 6 . This illustrates that the average respondent agrees that the Motivation Statement is related to being the boss, having control over time, trying new ideas, and increasing personal income have motivated to start your own business.

Respondents' answers to the valid and reliable Entrepreneurial Characteristics (JKKW) have an average value of 5 from the Likert scale range of 1 to 6 . This illustrates that the average respondent tends to strongly agree that Entrepreneurial Characteristics related to need to be confident, must be creative and innovative, self-motivated, and needs to work hard.

Respondents' answers to the Entrepreneurial Challenge (JKTW) did not pass the validity and reliability tests so they were not examined in this study. Respondents' 
responses to a valid and reliable Entrepreneurship Success (jkSK) have an average value of between 4 and 5 from the Likert scale range of 1 to 6 . This illustrates that the average respondent agrees that Success in Entrepreneurship is related to social contracts, the availability of money, and a good business idea.

\section{Perception of Undergraduate Students Studying Accounting for the Introduction to Information Technology.}

Referring to Sidiq \& Astutik (2017), indicators of perception of undergraduate students studying accounting for the introduction of Information Technology in this study are Infrastructure (PTI1), Networking (PTI2), Expertise (PTI3), Management (PTI4), Development (PTI5), and Collection (PTI6). Based on respondents' answers related to the introduction of Information Technology indicators for all valid statements can be seen in Table 3 above.

Respondents' answers to a valid and reliable infrastructure (PTI1) have an average value of 3.9537 from the Likert scale range of 1 to 6 . This illustrates that the average respondent quite agree that he is familiar with Infrastructure related to servers, storage subsystems, network devices such as switches, routers, and physical cables and special network equipment such as firewalls.

Respondents' answers to a valid and reliable Network (PTI2) have an average value of 4.2779 with a Likert scale ranging from 1 to 6 . This illustrates that the average respondent agrees to be familiar with Networks related to Local Area Networks (LAN), Metropolitant Area Network (MAN), and Wide Area Network (WAN).

Respondents' answers to a valid and reliable Expertise (PTI3) had an average value of 3.7602 from the Likert scale range of 1 to 6 . This illustrates that the average respondent quite agreed to know well the expertise related to cybersecurity \& mobile development, cloud \& distributed computing, data visualization and user interface design.

Respondents' answers to a valid and reliable Management (PTI4) have an average value of 3.8229 from the Likert scale range of 1 to 6 . This illustrates that the average respondent quite agreed to know well Management related to maintaining the course of Information Technology services at all times, optimize Information Technology costs, manage risk and complexity of Information Technology, achieve legal and regulatory compliance, manage higher volume changes, and align Information Technology services with business needs.

Respondents' answers to a valid and reliable Development (PTI5) have an average value of 4.2807 from the Likert scale range of 1 to 6 . This illustrates that the average respondent agrees to be familiar with Development related to e-government, ecommerce, e-education, e-medicine, and elaboratory.

Respondents' answers to a valid and reliable collection (PTI6) have an average value of 4.2561 from a range of Likert scale of 1 to 6 . This illustrates that the average respondent agrees to be familiar with collection related to operational functions, monitoring functions and control, planning and decision functions, communication functions, and interorganizational functions.

Perception of Undergraduate Students Studying Accounting for Understanding of Accounting Information Quality.

Referring to Matovu (2005), the perception indicators of undergraduate students studying accounting for the Quality of Accounting Information in this study are the Right Representation (KIART) and Relevance (KIARLV). Based on respondents' answers related to indicators of valid accounting information quality can be seen in Table 3 above. 
Respondents' answers to a valid and reliable Right Representation (KIART) have an average value of 4 from the Likert scale range of 1 to 6 . This illustrates that the average respondent agrees to have a good knowledge of the Right Representation related to the information does not contain fraud, complete, represent income well, represent the facts of expenditure well, represent business assets well, represent business liabilities well, and represent cash inflows and outflows well.

Respondents' answers to valid and reliable relevance (KIARLV) have an average value of 4 from the Likert scale range of 1 to 6 . This illustrates that the average respondent agrees to be well acquainted Relevance related to information helps predict and confirm income levels, information helps predict and confirm expenditure levels, information presented helps in making decisions regarding resource allocation, information helps respondents in making decisions about raising capital, information helps respondents confirm the results of planned activities, information helps respondents predict the results of planned activities, information helps the respondent in confirming the level of business profitability, information helps the respondent in confirming debt, and information helps the respondent to confirm the entry and exit of the business.

Positive relationship between the Entrepreneurial Soul and the Introduction of Information Technology to Understanding the Quality of Accounting Information.

Based on Figure 2 by looking at the correlation coefficient, the Correlation coefficient of Entrepreneurship (JK) of 0.539 to Accounting Information Quality (KIA) appears to be greater than the correlation coefficient for Introduction to Information Technology (PTI) of 0.157 to Quality of Accounting Information (KIA). The Entrepreneurial Soul and Introduction to Information Technology are both positively related to the Quality of Accounting Information. This indicates that if someone has a high entrepreneurial spirit, it will increase his understanding of the Quality of Accounting Information, and vice versa.

In addition, if someone has a high introduction to Information Technology will increase their understanding of the Quality of Accounting Information.

The results of this study are consistent with Sari and Yadnyana's (2017) research findings which are also in line with the results of Suhairi's (2004) and Krisanti (2012) studies that reveal that there is a positive and significant influence between the entrepreneurial spirit on the quality of accounting information. The results of this study are also in accordance with the results of Sari and Yadnyana's research (2017) which are in line with the results of research by Ismail and King (2007), Al-Eqab and Adel (2013), and Rahmadani (2015) which revealed that there was a positive and significant influence between sophistication of information technology with the quality of accounting information.

On the other hand, the results of this study are not in accordance with the results of the study of Galloway et al (2006) whose results found that there was no significant influence of the entrepreneurial spirit with the interests of students using accounting software and not in accordance with the results of Purnama (2013) and Rai et al. (2002) which found a different direction, namely the sophistication of information technology has a negative effect on the quality of accounting information.

\section{CONCLUSIONS}

The Entrepreneurial Soul (JK) and Introduction to Information Technology (PTI) have a positive and significant correlation value to the Quality of Accounting Information (KIA). It is also illustrated that the correlation coefficient of Entrepreneurial Soul to the Quality of Accounting Information is higher than the 
Introduction of Information Technology to Quality of Accounting Information.

The results of this study are consistent with Sari and Yadnyana (2017), Suhairi (2004) and Krisanti (2012) research results, which reveal that there is a positive and significant influence between the entrepreneurial spirit on the quality of accounting information. The results of this study are also in accordance with the results of Sari and Yadnyana's research (2017), Ismail and King (2007), Al-Eqab and Adel (2013), and Rahmadani (2015) who revealed that there is a positive and significant influence between the sophistication of information technology with quality accounting information. In addition, this is as stated by Ajzen (1991) in Wahyono (2014) that Theory of Planned Behavior (TPB) is very suitable to be used to explain various entrepreneurial behaviors that require planning, in this case to produce quality accounting information.

This study has several limitations including the research conducted in the sampling period, which is only in the odd semester of the academic year 2017/2018. In addition, the questionnaire was only distributed to several universities, namely Untar, STIE Trisakti, Ukrida, and UPH and only S1 students who studied accounting. Based on the above limitations, for further research studies should be carried out in several periods so that more consistent the perception of respondents.

Further research is also recommended for wider dissemination to various other tertiary institutions and to all undergraduate, graduate and postgraduate students who study accounting and who have run businesses.

\section{REFERENCES:}

Sidiq, Ahmad dan Emi Puji Astutik. 2017. Analisis Kapabilitas Teknologi Informasi Terhadap Kinerja Bisnis UKM dengan Orientasi Pelanggan sebagai Variable Intervening (Studi pada UKM Sektor Manufaktur di Wilayah Solo Raya). Media Ekonomi dan Manajemen, 32(1), Jan.

Kabui, Elizabeth W dan Jackson K Maalu. 2012. Perception of Entrepreneurship as a Career by Students from Selected Public Secondary Schools in Nairobi.DBA Africa Management Review, 2(3), 101-120.

Lestari, Agustina Dwi dan Nur Fadjih Asyik. 2015. Pengaruh Kualitas Sistem Informasi dan Pengetahuan Akuntansi Terhadap Kualitas Informasi Akuntansi. Jurnal Ilmu \& Riset Akuntansi, 4(9).

Maharsi, Sri. 2000. Pengaruh Perkembangan Teknologi Informasi Terhadap BidangAkuntansi Manajemen. Jurnal Akuntansi \& Keuangan, 2(2), Nopember; 127-137.

Martz, W. Benjamin Jr; Thomas C Neil, Alessandro Biscaccianti, dan Robert J Williams. 2003. Entrepreneurship (Comparative Analysis). International Journal of Entrepreneurship. Annual 7.

Matovu, Bakisa Harriet. 2005. Perceived Quality of Accounting Information and Performance of Small and Medium Enterprises; MSc. Accounting and Finance A Research Dissertation Submitted to Makerere University Business School.

Nian, Teh Yi, Rosni Bakar, dan MD. Aminul Islam. 2014. Students' Perception onEntrepreneurship Education: The Case of Universiti Malaysia Perlis. International Education Studies, 7(10).

Sari, Ida Ayu Komang Tiara Pratistha dan I Ketut Yadnyana 2017. Pengaruh Kecanggihan Teknologi Informasi dan Jiwa Kewirausahaan Terhadap KualitasInformasi Akuntansi. E-Journal Akuntansi Universitas Udayana, 18(2), Febuari, 1635-1662.

Susanto, Patricia. 2016. Nilai-Nilai Perusahaan Keluarga. Bisnis Indonesia. CEO The Jakarta Consulting Group. www.jakartaconsulting.com

Wahyono, Budi. 2014. Teori Perilaku yang Direncanakan (Theory of Planned Behavior) www.pendidikanekonomi.com

Yuliana, Oviliani Yenty. 2000. Penggunaan Teknologi Internet dalam Bisnis. Jurnal Akuntansi dan Keuangan, 2(1), Mei, 36-52. 